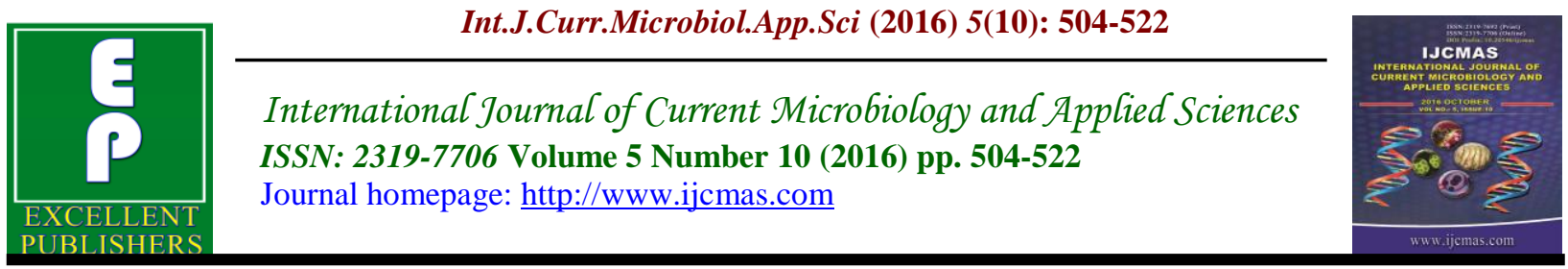

Review Article

http://dx.doi.org/10.20546/ijcmas.2016.510.056

\title{
Intercropping System, Rhizobia Inoculation, Phosphorus and Potassium Fertilization: A Strategy of Soil Replenishment for Improved Crop Yield
}

\author{
Daniel Nyoki ${ }^{1,2}$ and Patrick A. Ndakidemi ${ }^{1}$ * \\ ${ }^{1}$ School of Life Science and Bio-engineering, The Nelson Mandela African Institution of Science \\ and Technology, P.O. Box 447, Arusha, Tanzania \\ ${ }^{2}$ Regional Commissioner's Office, P.O Box 5095 Tanga, Tanzania \\ *Corresponding author
}

\section{Keywords}

Biological nitrogen

fixation, soil fertility, nutrient uptake, Land equivalent ratio, food security.

\section{Article Info}

Accepted:

18 September 2016

Available Online:

10 October 2016

\section{A B S T R A C T}

The significant constraint to legumes and cereal crop production in most subSaharan Africa countries is the loss of soil fertility. The most limiting soil nutrients are nitrogen $(\mathrm{N})$, phosphorus $(\mathrm{P})$ and potassium $(\mathrm{K})$ which to the great extent cause low grain yields. The main reason for declining of these nutrients in the soil is the mining through continued cultivation without external input application. These nutrients are not usually applied by farmers because of their high prices leading to poor crop growth, development and finally poor yield. Leguminous crops have ability to form symbiotic relationship with rhizobia and fix atmospheric nitrogen. The fixed nitrogen can be used by legume plant themselves or might be transferred and be utilized by other plants growing nearby in intercropping systems or can be used by plants grown in the subsequent season. This review focus on understanding how rhizobia inoculation, intercropping system, and fertilization with $\mathrm{P}$ and $\mathrm{K}$ influences nitrogen fixation; mineral composition in the crop rhizosphere; nutrient uptake in plants; plant growth; photosynthesis and leaf chlorophyll formation; land equivalent ratio and ultimately yield performance of legumes and cereals. The results from different literatures cited showed that rhizobia inoculation and supplementation with phosphorus and potassium had positive significant effects on all parameters measured. Therefore, based on the findings reported, it can be recommended, to use rhizobia inoculants supplemented with optimum levels of phosphorus and potassium in intercropping systems as a strategy for improving crop production.

\section{Introduction}

Loss of soil fertility is one of the important constraints to legumes and cereal crop production in sub-Saharan Africa countries (Buerkert et al., 2001). The most limiting nutrients are nitrogen $(\mathrm{N})$, phosphorus $(\mathrm{P})$ and potassium (K) (Bekunda, et al., 2004), which to the great extent cause low grain yields. However, $\mathrm{N}$ is abundantly (80\%) available in the air, existing in a form that cannot be used by plants (Santi et al., 2013) until it is fixed in either natural ways or through biological agents of nitrogen fixation. This nitrogen is very important for plant/crop growth and development, short of 
its supply to plants results in stunted growth. The deposits of $\mathrm{K}$ are relatively plenty, but the phosphate reserves are increasingly becoming scarce (Roy, 2006). The dependence of crop growth on nitrogen and the limited bioavailability of this element have resulted in a massive $\mathrm{N}$-based fertilizer industry worldwide which led to increased use nitrogenous fertilizers to meet the global food demand (Westhoff, 2009; Santi et al., 2013). However, these nitrogenous fertilizers go in opposite direction with the current global theme of climate smart agriculture as they cause greenhouse gas emission $\left(\mathrm{N}_{2} \mathrm{O}\right)$.

Leguminous crops are well known for their ability to fix atmospheric nitrogen (Ledgard and Steele, 1992; Peoples et al., 1995). This nitrogen is used by the legume crops themselves or might be excreted out of legume's root structures called nodules into the rhizosphere soil and be utilized by other plants growing nearby in intercropping systems (Andrew, 1979; Shen and Chu, 2004). Furthermore, the fixed nitrogen can be used by plants grown in the succeeding season following the death and subsequent mineralization of diazotrophs (James, 2000). For example, Shen and Chu, (2004) reported that at the low rate of applied $\mathrm{N}$; rice could utilize some $\mathrm{N}$ from peanut during the period of their co-growth. Furthermore, it was reported that inter specific root interactions between faba beans intercropped with maize played a significant role in the yield benefit of maize in an intercropping system (Li et al., 1999; Zhang and Li, 2003). Following the yield advantage in an intercropping system, it was thought that the nitrogen that was fixed by faba beans may have been transferred to maize and increase the maize yield (Zhang and $\mathrm{Li}, 2003$ ) suggesting the importance of intercropping legumes with cereals.
Intercropping is an old and common agricultural practice of growing more than one crop in the same field at the same time (Sanchez, 1976). It is mainly practiced in sub Saharan Africa (SSA), by smallholder famers (Matusso et al., 2014). Most common crop combinations in intercropping systems include: maize-cowpea, maizepigeon pea, maize-soybean, maizegroundnuts, maize-beans, maize-lablab, sorghum-cowpea, millet-groundnuts, and rice-pulses (Matusso et al., 2012). This cropping practice aims to match efficiently crop demands to the available growth resources and labor (Dahmardeh et al., 2010; Lemlem, 2013). The efficient use of available growth resources in a given piece of land and eventually maximizing productivity is the primary advantage of intercropping crops of different height, canopy structure, rooting ability, and nutrient requirements (Lemlem, 2013; Ghanbari et al., 2010). Many studies on intercropping have shown that legumescereal intercropping is an important productive and sustainable system due to its resource facilitation and significantly enhancing crop productivity as compared with that of monoculture crops (Jensen, 1996; Ghanbari et al., 2010; Dahmardeh et al., 2010). In an effort to improve food security, intercropping cereals with legumes plays an important role by providing a farmer with both carbohydrates and proteins for their dietary needs. Apart from nutritional composition of component crops in an intercropping, it has been also reported that intercropping improves soil fertility through biological nitrogen fixation, increases soil conservation through greater ground cover than sole cropping (Lemlem, 2013), and provides better protection against crop pests and diseases than when grown in monoculture (Matusso et al., 2012). 
Despite of increased global mineral fertilizer use accelerated by global food demand, smallholder farmers in SSA usually experience low crop productivity (Mwangi, 1996). This might be due to continued cropping without addition of external inputs leading to low levels of soil nutrients.

On the other hand, unavailability of specific rhizobia strain would reduce the biological nitrogen fixation, and consequently result in low grain yields in intercropping systems. Grain yields of both legumes and cereals can potentially improve from the application of moderate levels of chemical fertilizers (Ndakidemi et al., 2006). However, these inputs are rarely used by farmers either because of their skyrocketing prices (Ndakidemi et al., 2006; Chianu et al., 2011), lack of farmer's awareness on their economic returns, or both (Ndakidemi et al., 2006).

The use of these inorganic fertilizers has also made prices of many agricultural commodities to skyrocket (Masarirambi, 2010). Therefore, there is a need to find out simple, cheap and environmentally friendly methods of improving agricultural productivity through Integrated Soil Fertilty Management (ISFM). Rhizobia inoculation, intercropping systems, and fertilization with moderate levels of phosphorus and potassium may have great potentials as an ISFM strategy for changing the response of crops in different parameters.

The aim of this article is to critically review and explore how rhizobia inoculation, intercropping system, and fertilization with $\mathrm{P}$ and $\mathrm{K}$ influences nitrogen fixation; mineral composition in the crop rhizosphere; nutrient uptake in plants; plant growth; photosynthesis and leaf chlorophyll content; land equivalent ratio and finally yield performance of legumes and cereals.
Biological nitrogen fixation in legumes under rhizobia inoculation, phosphorus and potassium fertilization, and its associated benefits to the cereal component

\section{Biological nitrogen fixation and their associated benefits to the cereal crop}

Rhizobia are microorganisms that are employed to improve the availability of nutrients such as nitrogen through atmospheric $\mathrm{N}_{2}$ fixation. These microorganisms are also called biofertilizers. In recent years, biofertilizers have emerged as a vital component for biological nitrogen fixation providing an economically attractive and ecologically sound way for increasing nutrient supply (Shridhar, 2012). Legumes such as soybean, lablab, common bean, cowpea and ground nuts are important hosts for these microorganisms to perform biological nitrogen fixation. Biological $\mathrm{N}_{2}$-fixation and mineral soil or nitrogenous fertilizers are the major sources of meeting the $\mathrm{N}$ requirement of high yielding legumes. Recently, it was reported that about $50-60 \%$ of soybean $\mathrm{N}$ demand was met by biological $\mathrm{N}_{2}$ fixation (Salvagiotti et al., 2008). Soybean (Glycine max) is a crop grown in different parts of the world.

It is a popular nutritious crop providing human with a very high proteins and it is of high economic importance (Raji, 2007). The popularity of this crop is not based only on its high protein content but also its ability to fix atmospheric nitrogen thereby contributing to soil $\mathrm{N}$ and improve soil quality. When legume crops are inoculated with the right strain of rhizobia, they are able to fix atmospheric nitrogen and contribute to the soil nitrogen to meet plant $\mathrm{N}$ requirements (Salvagiotti et al., 2008). In a natural ecosystem, legumes can fix 
nitrogen in the range of $25-75 \mathrm{lb}$ which is equivalent to $11.34-34.02 \mathrm{~kg}$ of nitrogen per acre per year (Flynn and Idowu, undated). In cropping systems for example perennial legumes such as Alfalfa, sweet clovers, true clovers, and vetch may fix up to $250-500 \mathrm{lb}$ of nitrogen per acre per year (Walley et al., 1996). Likewise, grain legumes such as peanuts, cowpeas, soybeans, and fava beans, can fix up to $250 \mathrm{lb}$ which is equivalent to $113.4 \mathrm{Kg} \mathrm{N} \mathrm{ha}{ }^{-1}$ (Flynn and Idowu, undated). The fixed nitrogen is of beneficial to the cropping systems as it is not only used by the fixing crop but also non fixing crops growing nearby may consume this nitrogen when are released out of the fixing plants (Shen and Chu, 2004).

For example, a total of $17.08 \mathrm{~kg} \mathrm{~N} \mathrm{ha}^{-1}$ was transferred from legumes to the nonlegumes in the mixture (Frankow-Lindberg and Dahlin, 2013). However, studies on dinitrogen fixation in complex cereal/legume mixtures are few (Stern, 1993; Peoples et al., 2002) as reviewed by Ndakidemi (2006). Therefore, there is a need to conduct study that will explore the response of legumes inoculated with rhizobia on nitrogen fixation so as to add knowledge on existing information. Furthermore, studies are also required to quantify the amount of nitrogen that can be fixed by specific legumes in different environments and cropping systems and how much of these nitrogen can be used by cereal crops in an intercropping systems.

\section{Phosphorus and potassium fertilization on nitrogen fixation in legumes}

$\mathrm{N}_{2}$-fixation by Rhizobium bacteria in leguminous plants is favoured by similar conditions necessary for good growth, vigour and dry matter production of the host plant. These conditions include availability of mineral elements such as starter $\mathrm{N}$, phosphorus (P) and potassium (K). The primary source of nutrients $(\mathrm{P}$ and $\mathrm{K}$ ) is weathering of bedrock, and the availability trend of these nutrients tends to decline with time as soils age (Hedin et al., 2003). Apart from their biochemical and physiological functions in the plants, these elements have other function of enhancing biological nitrogen fixation.

The influence of phosphorus on symbiotic $\mathrm{N}_{2}$-fixation in leguminous plants has been studied intensively and many researchers have reported that phosphorus improved nitrogen fixation in legumes (Tang et al., 2001; Ndakidemi et al., 2006; Zafar et al., 2011). Israel (1987), reported that severe phosphorus deficiency significantly impaired both host plant growth and symbiotic $\mathrm{N}_{2}$ fixation, indicating that $\mathrm{N}_{2-}$ fixation has a higher phosphorus requirement for optimal functioning than that required for host plant growth and nitrate assimilation. Potassium plays an important role in the process of nitrogen fixation (Mengel et al., 1974). Potassium is essential in photosynthesis, as it maintains and balances the electrical charges at ATP production site, and also helps to promote translocation of photosynthetic substances (carbohydrate) to storage organs (fruits or roots) (Uchida, 2000).

Carbohydrate produced by the host plant is also translocated to other parts of the plants including nodules where it is used by nitrogen fixing bacteria as a source of energy to fix atmospheric nitrogen (Mengel et al., 1974). Regardless of the effects of these mineral elements $(\mathrm{P}$ and $\mathrm{K})$ on dinitrogen fixation, there is a need to conduct a study to assess their combined effects on nitrogen fixation in legumes growing in association with maize. 
Mineral composition in the rhizosphere of legumes and cereals under intercropping system, rhizobia inoculation, phosphorus and potassium fertilization

\section{Effects of rhizobia inoculation on rhizopheric mineral composition}

Inoculation of legumes with specific strain of Rhizobium is well known for its ability to increase $\mathrm{N}_{2}$ fixation, plant yield and also improve the seed quality (Saini et al., 2004; Bambara and Ndakidemi, 2010). A group of soil dwelling and beneficial non pathogenic bacteria are referred to as plant growth promoting rhizobacteria (PGPR). PGPR colonizes the rhizosphere of diverse plant species and confer beneficial effects, such as increased plant growth by providing plants with fixed nitrogen and reduced susceptibility to diseases resulting from plant pathogenic bacteria, viruses, fungi, and nematodes (Kloepper et al., 2004 Yang, et al., 2009).

Some PGPR also shows physical or chemical changes in the rhizosphere which is related to plant growth and plant defense (Yang, et al., 2009). A study conducted by Bambara and Ndakidemi (2010) on common bean ( $P$. vulgaris) showed that Rhizobium inoculation significantly increased soil $\mathrm{pH}$, $\mathrm{Ca}$ and $\mathrm{Na}$ availability.

In their study, they also reported a significant increase in available micronutrients such as $\mathrm{Fe}, \mathrm{Cu}, \mathrm{Zn}$ and $\mathrm{Mn}$ following Rhizobium inoculation when compared with the control. However, little information is available about the effect of rhizobia inoculation on the chemical composition of rhizosphere of intercropped plants. Studies are needed to explore more information about the effects of rhizobia inoculation on mineral composition in the rhizosphere of intercropped plants.

\section{Rhizospheric mineral composition under} legume-cereals mixtures

In past few decades, intensification of agricultural systems have increased and reduced crop diversity to one or few species that are sometimes genetically homogenous with the uniform planting arrangements (Mobasser et al., 2014). Traditionally, small-holder subsistence farmers in the tropics have the tendency of intercropping their land to keep the associated risks of monocultures and assure stable income and nutrition (Francis, 1986). Intercropping cereal with grain legume crops facilitate the improvement and maintenance of soil fertility, because legume crops such as cowpea, mungbean, soybean and groundnuts are reported to accumulate from 80 to 350 kg nitrogen $(\mathrm{N}) \mathrm{ha}^{-1}$ (Peoples, and Craswell, 1992). Intercropping have been reported to have indirect effect in the rhizospheres of intercropped species by enhanced nutrient mineralization because of the changes in soil organic matter decomposition rates, resulting from the addition of fresh organic matter (Blagodatskaya and Kuzyakov, 2008; Mobasser et al., 2014). A study done by Bolan et al., (1991) has shown that plants fixing nitrogen may cause changes in soil $\mathrm{pH}$, which may limit the availability of some mineral elements. Other studies have reported that there were changes in physical and chemical characteristics of rhizosphere following intercropping (Zhang et al., 2004). Specifically, Song et al., (2007) reported that intercropping augmented microbial biomass and increased the availability of $\mathrm{C}$, $\mathrm{N}$ and $\mathrm{P}$ in the rhizosphere. However, there is little information on mineral composition of rhizosphere influenced by association of cereals and legumes inoculated with rhizobia. Hence, calling for more studies to explore on how these interactions and association affects chemical and mineral composition of rhizosphere soil in cereals and legumes. 
Nutrient uptake in legumes and cereals under intercropping, rhizobia inoculation, phosphorus and potassium fertilization

\section{Below ground interaction of legumes and cereals affects nutrient uptake}

Many studies on intercropping have generally paid attention on the legumecereal intercropping and assess yield performance of the crops taking advantage better resource utilization (Li et al., 1999; Andersen et al., 2007; Agegnehu et al., 2008; Hauggaard-Nielsen et al., 2009). When plants are grown in mixture they have potentials of modifying nutrient availability in the soil by releasing exudates from their roots (Raynaud et al., 2008). These exudates may contain various chemical compounds like organic anion, amino acids, protons, sugars and enzymes which are believed to modify nutrient availability for the plants and hence improve yield (Raynaud et al., 2008). Morris and Garrity (1993) have reported the close association between yield advantage and plant nutrient uptake by intercropped plant species. Further studies by Hauggaard et al. (2009) showed that accumulation of nutrients such as phosphorus $(\mathrm{P})$, potassium $(\mathrm{K})$, and sulphur (S) may be enhanced by the nutrient complementarity of intercropped pea and barley and further postulated that these might have influenced the overall crop yield and thereby increasing competitive ability of capturing and utilization of other resources. $\mathrm{P}$ uptake has been reported to be influenced by intercropping in many studies (Mobasser et al., 2014). Specifically, it was reported that there were increased uptake of $\mathrm{P}$ in white lupin intercropped with wheat (Gardner and Boundy, 1983; $\mathrm{Cu}$ et al., 2005). Other study by Ae et al. (1990) showed that pigeon pea influenced the uptake of $\mathrm{P}$ in the sorghum in an intercropping. The literature has pointed out that intercropping legume with cereals may improve uptake of some mineral element, however, we would like explore how uptake of both macro and micro nutrients is affected by plant grown in an intercropping systems.

\section{Influence of rhizobia inoculation on nutrient uptake in plant tissues}

Uptake of plant nutrients is an essential process as these nutrients needed by plants for normal growth and development. Nutrient uptake by plants depends on the amount, concentration, rhizosphere processes and the capacity of soil to replenish nutrient in the soil (Makoi et al., 2013). Microorganisms such as rhizobia as well as other plant growth promoting rhizobacteria, are said to change the chemistry of nutrients in the soil and make them available for uptake by plants (Saharan and Nehra, 2011). Rhizobial inoculants are reported to increase uptake of nutrients such as $\mathrm{N}$ and $\mathrm{P}$ though the biological nitrogen fixation thereby improving $\mathrm{N}$ availability to plants (Ndakidemi et al., 2011). They can also mobilize both organic and inorganic phosphorus from organic as well as inorganic sources making them available in the rhizosphere for uptake by plant (Matiru and Dakora, 2004). Recent studies (Fatima et al., 2007; Ndakidemi et al., 2011; Makoi et al., 2013; Nyoki and Ndakidemi 2014a, b; Tairo and Ndakidemi 2014) have reported that the rhizobia inoculation have influenced and increased the uptake of different nutrients in plants. For example, Makoi et al. (2013) reported a significant increase in the uptake of $\mathrm{P}, \mathrm{K}, \mathrm{Ca}$, and $\mathrm{Mg}$ in plant tissues. Similarly, Ndakidemi et al. (2011) working on $P$. vulgaris reported a significant increase in uptake of micronutrients $\mathrm{Fe}, \mathrm{Cu}$, $\mathrm{Zn}, \mathrm{Mn}, \mathrm{B}, \mathrm{Mo}$ in different plant tissues. Regardless of many studies conducted on 
intercropping there are few research reports specifically in Tanzania about the role of intercropping and rhizobia inoculation on nutrient uptake in legumes intercropped with cereals. Therefore, there is a need to conduct research investing the influence of cereallegumes intercropping systems and rhizobia inoculation supplemented with phosphorus and potassium on plant nutrient uptake.

\section{$P$ and $K$ fertilization on other nutrient uptake by plants}

Nutrients such as phosphorus and potassium play different important roles in plant growth and development thereby increasing biomass and grain yield. Bioavailability and uptake of these nutrients is constrained by different factors including their concentration in the soil (Makoi et al., 2013), $\mathrm{pH}$ of the soil (Bambara and Ndakidemi, 2010) and the nature of exudates produced by the plants (Raynaud et al., 2008). $\mathrm{P}$ is reported to facilitate plant roots development and enhances nodules of the legume plants so that increases seed yields (Hayat et al., 2010). Plants supplied with mineral elements $\mathrm{P}$ and $\mathrm{K}$ will easily capture and take up the supplied elements and may influence the uptake of other nutrients. For example, Islam et al., (2008) reported an increased phosphorus uptake in rice with increasing application of $\mathrm{P}$ rates. Akram et al., (2007) showed that nitrogen uptake in sorghum was improved with application of $\mathrm{P}$ and $\mathrm{K}$, pointing out that their combined use exceeded their alone application. In recent study conducted by Nyoki and Ndakidemi (2014a, b), it was reported that phosphorus supplementation improved micro and macro nutrient uptake in different tissues of cowpea grown under the field and screen house condition. Another study reported that application of $\mathrm{K}$ helped the release of fixed $\mathrm{NH}^{4+}$ ion from the soil and this enabled the crop to better uptake of nitrogen (Sharma and Ramna, 1993). To obtain the maximum yield, plants need to be supplied with the optimum mineral nutrients they require. However, the crops are not supplied with these nutrients by many smallholder farmers in sub-Saharan Africa, leading to poor crop growth, development and finally poor yield. More studies are proposed to assess the factors influencing nutrient uptake in $\mathrm{P}$ and $\mathrm{K}$ treated crops and what are the associated benefits of improved nutrient uptake to the human diet.

Growth performance of legumes and cereals as affected by rhizobia inoculation supplemented with phosphorus and potassium in intercropping system

\section{Growth performance of crops under intercropping systems}

Growth performance is one of the indicators of crop yield performance. Plant growth is affected either positively or negatively by different factors including cropping patterns (Carr et al., 2004; Dusa and Stan, 2013). The effects of intercropping on growth performance of intercropped crops have been studied for a long time and many researchers have reported different findings. Hirpa (2014) reported that there was significant increase in maize height just by delaying planting date of haricot bean for three weeks after planting maize as compared with the simultaneous planting maize and haricot bean. In another study, Hirpa (2013) reported that there was a significant interaction of intercropped legume species and intercropping time resulting in an increase in maize height simultaneously planted with legumes and gave the reason that maize height could have been contributed by inter-specific competition to avoid over shading. Lemlem (2013) recorded a significant difference in 
plant height where it was found that the height of sole maize was significantly higher than maize-lablab and maize-cowpea intercropping. However, there is little information reported on the effects of legume-cereals intercropped at different spacing on growth performance particularly in depleted soils. Studies on intercropping cereals with legumes at different spacing would provide more information on growth performance of crops grown in mixture and different spacing.

\section{Growth performance of crops as affected by rhizobia inoculation}

Rhizobia inoculation is well known for its effects on biological nitrogen fixation when comes in symbiotic relationship with leguminous plants. The improved nitrogen fixation is very important for the crop growth and development. Several studies have shown that there is evidence of improved plant growth following rhizobia inoculation.

For example, Yamanaka et al., (2005) reported that there was a significant increase in biomass in the Alnus sieboldiana seedlings inoculated with Frankia and Gigaspora margarita when compared with un-inoculated seedlings. Unavailability of specific strain of rhizobia reduces the growth of leguminous crops to the great extent (Vincent et al., 1979).

Poor symbiosis between Rhizobium and legumes are reported to reduce the amount of fixed nitrogen in legumes resulting in reduced plant growth (Bambara and Ndakidemi, 2009). Furthermore, a study done by Bambara and Ndakidemi (2010) showed the presence of significant increase in fixed nitrogen in different plant tissues of Phaseola vulgaris relative to un-inoculated treatments. The improved $\mathrm{N}$ nutrition improves plant growth as well as yield performance. Many research on influence of rhizobia on plant focus on growth performance of the fixing crop without considering the effect of rhizobia on growth of neighbouring non fixing plants. It is therefore important to conduct studies to assess how rhizobial inoculation may influence growth performance of both fixing and non-fixing plant.

\section{Growth performance of crops under phosphorus and potassium fertilization}

Mineral elements such as $\mathrm{N}, \mathrm{P}$ and $\mathrm{K}$ plays important roles in plant growth and development and ultimately determination of crop yield (Uchida, 2000). Both elements are essential macronutrients required in relatively large amount by plants. Being one of the important element for plant growth, phosphorus is found in every living plant cell playing role in various plant functions including energy transfer, photosynthesis, translocation of sugars and starches as well as movement of nutrients within the plant (Brady, 2002; Shahid et al., 2009).

Potassium is required by plants for a number of vital physiological processes including the following: activation of several enzymes, synthesis and degradation of carbohydrates, production of proteins as well as regulation of stomata pores for gas exchange and photosynthesis (Lissbrant et al., 2009).

However, $\mathrm{P}$ and $\mathrm{K}$ are usually very low in the soils, a condition which limit proper plant growth resulting in stunted crops and hence poor yields. Therefore, for proper plant growth and development, more studies are of utmost important to investigate the effects of different levels of $\mathrm{P}$ and $\mathrm{K}$ on plant growth in different soil condition and different cropping systems. 
Photosynthesis and chlorophyll formation as affected by rhizobia inoculation, phosphorus and potassium fertilization in legume-cereals mixtures

\section{Photosynthesis and chlorophyll formation in crops as influenced by rhizobia inoculation}

Chlorophyll can be referred to as a green molecule found in plant cells which plays the central function in photosynthesis. Photosynthesis is a process by which plants captures sun light and convert it to useful chemical energy in presence of water, carbon dioxide and chlorophyll (Amesz, 1987).

Life on earth would be not possible without photosynthesis because it creates living matter out of inert organic material, replenishes the reservoirs of oxygen in the atmosphere and store light energy from sun to support the life activities of nearly all organisms (Rabinowitch and Govindjee, 1969; Gaidos, 1999). Inoculation of rhizobia may affect the whole plant photosynthesis because they tend to improve plant nutrition and growth by increasing total leaf area (Kaschuk, et al., 2009).

Another study showed that $P$. vulgaris $\mathrm{L}$. inoculated with rhizobia had an increased leaf chlorophyll content compared with uninoculated plants (Bambara and Ndakidemi, 2009). Research evidence shows that Rhizobium inoculation increases the chlorophyll content of leaves (Arumugam $e t$ al., 2010), and hence improves plant biomass production. However, rhizobia inoculation under cereal-legume intercropping systems still needs more studies to assess its effects on leaf chlorophyll content of both components of intercropping.
Phosphorus and potassium fertilization on the photosynthesis and chlorophyll formation in crops

Declining soil fertility, especially mineral nutrients such as $\mathrm{N}, \mathrm{P}$ and $\mathrm{K}$ has continued to cause low yield for many farmers in SSA. The limited supply of these elements is reported to impair plant growth in terms of cell division and expansion, and photosynthesis (Hossain et al., 2010; Longstreth and Nobel, 1980). Potassium $\left(\mathrm{K}^{+}\right)$is one of the abundant ion in the plant cells being required for various functions including maintenance of electrical potential gradients across plasma membrane and also it activates the function of various enzymes (Britto and Kronzucker, 2008). Apart from these functions in plants $\mathrm{P}$ and $\mathrm{K}$ play an important role in the photosynthetic activities and chlorophyll formation in plants. For example, in the past few years one group of researchers reported an increase in chlorophyll content following application of phosphorus on the seedlings of Larix olgensis (Wu et al., 2006). Recent studies have also shown that the plants treated with relatively high levels of $\mathrm{P}$ and $\mathrm{K}$ improved chlorophyll a, $\mathrm{b}$ and $\mathrm{ab}$ production in cotton leaves (Onanuga et al., 2011). This report is in line with the previous study by Lamrani et al. (1996) who reported that $\mathrm{K}$ nutrition promoted formation of both chlorophyll $\mathrm{a}$ and $\mathrm{b}$ in cucumber leaves, and that $\mathrm{K}$ deficient is associated with low chlorophyll content on cotton (Zhao et al., 2001).

\section{Photosynthesis and chlorophyll formation} as affected by intercropping systems

Intercropping has been reported to bring about yield advantages over sole crop by many researchers (Giller and Wilson, 1991; Khogali et al., 2011, Lemlem, 2013). However, this may lead to the suppression 
of one of the companion crop in the mixture by preventing the sunlight from reaching the crop. Sunlight is normally captured by plant leaves and converted into chemical energy to be used for various plant activities. It was previously reported by Islam et al., (1993) that Mungbean intercropped with sorghum suffered a shading stress at different growth stages. It was further reported that grain filling stage is very much light sensitive. For instance, Yoshida and Hara, (1977) reported low light intensity causes a slight delay in the grain filling of the whole panicle and reduced the percentage of filled grains on the lower branches of Indica and Japonica rice. Therefore, there is a need to conduct further studies to assess the effects of intercropping on chlorophyll formation in legumes intercropped with cereals. This will help us better understand how intercropping may affect chlorophyll formation and photosynthesis there by affecting grain and biomass production.

Yield performance of legumes and cereals as influenced by rhizobia inoculation and $P$ and $K$ fertilization in intercropping systems

\section{Yield performance of legumes and cereals in mixed culture}

Intercropping is an agricultural practice of growing more than one crop in the same piece of land at the same time aiming at efficiently matching the available growth resources to the crop demands (Banik and Bagchi, 1993; Zhu et al., 2000; Xu et al., 2008). Many studies have reported that most advantage of intercropping is production of greater yield on a given piece of land (Giller and Wilson, 1991; Ndakidemi and Dakora, 2006; Khogali et al., 2011, Lemlem, 2013). Intercropping maize with grain legumes is the traditional farming practice believed to reduce the risk of crop failure, and add some
$\mathrm{N}$ to the system through biological $\mathrm{N}$ fixation (Whitbread, 2004). The most probable reason for production of greater yield in an intercropping system is the addition of $\mathrm{N}$ in the soil from biological nitrogen fixation (BNF) (Whitbread, 2004; Khogali et al., 2011), better utilization of available growth resources (water, nutrients, light and air) (Morris and Garrity, 1993; Zhu et al., 2000; Li et al., 2003), better use of available piece of land (Singh and Usha, 2003), and interspecific interactions and facilitation of the component crops (Zhang, 2003; Fan et al., 2006). Li et al., (2001) stated that the crops grown in the mixture, such as cereals and legumes may have a series of complex inter- and intra-specific interactions which leads to an increased crop yield. However, Ndakidemi et al., (2006) reported that African soils are heavily mined for nutrients, especially $\mathrm{N}$ and $\mathrm{P}$, with a consequent decline in crop yields. Although many researchers have been done on yield advantage of legumes intercropped with cereals, there is a need to conduct further studies on the factors influencing greater yield in an intercropping systems.

Rhizobia inoculation on yield performance of legumes and cereals in mixture

Crop production in most smallholder farmers of sub-Saharan Africa is characterized by continuous cropping with low or no external inputs application resulting in reduced soil fertility and low agricultural productivity. As poor and hungry people cannot afford to purchase mineral fertilizers (Ndakidemi et al., 2006), they need low cost and readily available technologies and practices to increase food production (Pretty et al., 2003). Inoculation of rhizobia could be simple and affordable technology from which a farmer can increase crop yield. Rhizobia are soil 
bacteria which colonizes the roots of leguminous plants and form nodules in which biological nitrogen fixation takes place (Mia and Shamsuddin, 2010). Nitrogen is a macro element being required by plants in a relatively large amount than other elements (Cechin and de Fátima, 2004). It is required in large quantity by crops for maximum growth and development. Many studies have shown that rhizobia inoculation improved both crop growth and grain yields (Menaria et al., 2004; Popescu, 1998; Zahran, 1999; Vargas et al., 2000; Hernandez and Cuevas, 2003). In an intercropping of cereals and legumes, rhizobia inoculation enables nitrogen fixation and the fixed nitrogen is used by both legumes and cereals growing together in an intercropping systems thereby enhancing yield performance of cereals.

Phosphorus and potassium fertilization on yield performance of cereals and legumes in the mixed systems

For proper plant growth and development, the soil must be fertile and contain appropriate levels of essential mineral elements (Bationo et al., 2002; White et al., 2012). A fertile soil provides essential mineral nutrients for crop plant growth, supports a varied and active biotic community (Mäder et al., 2002). The essentiality of elements is based on Arnon and Stout, (1939), who stated that "an element is not considered essential unless: $\mathrm{i}$ ) a deficiency of it makes it impossible for the plant to complete the vegetative or reproductive stage of its life cycle; ii) such deficiency is specific to the element in question, and can be prevented or corrected only by supplying this element; and iii) the element is directly involved in the nutrition of the plant quite apart from its possible effects in correcting some unfavorable microbiological or chemical condition of the soil or other culture medium". The most important plant nutrients for production of high yields are nitrogen $(\mathrm{N})$, phosphorus $(\mathrm{P})$ and potassium $(\mathrm{K})$. Among these elements, $\mathrm{N}$ is abundant in the air, and deposits of $\mathrm{K}$ are relatively plenty, but the phosphate reserves are increasingly becoming scarce (Roy, 2006). Potassium is involved in the translocation of photosynthetic products (sugars) for plant growth or storage in fruits or roots (Uchida, 2000). Phosphorus performs many functions in plants including the following: it is a part of the RNA and DNA structures which are the main components of genetic information; it is required in large quantities in young cells, such as shoots and root tips where metabolism is high and cell division is rapid; it aids in root and nodules development, flower initiation, and seed and fruit development (Uchida, 2000; Mokwunye and Bationo, 2002). Studies have shown that plants supplied with appropriate amount of $\mathrm{P}$ has resulted in increased yields over the control (Ndakidemi et al., 2006; Zafar et al., 2011). However, most soils in some Eastern Africa countries have negative balances of $\mathrm{N}, \mathrm{P}$ and $\mathrm{K}$ which limits crop production (Bekunda et al., 2004) (Table 1). The limited availability of soil nutrients, calls upon crop scientist to conduct studies to investigate the response of crops supplied with $\mathrm{P}$ and $\mathrm{K}$ at different levels in an intercropping systems on crop yields. 
Table.1 Calculated nutrient balances of N, P and K (kg ha-1year-1) of the arable land for some Eastern Africa countries

\begin{tabular}{|l|c|c|c|c|c|c|}
\hline Country & \multicolumn{2}{|c|}{$\mathrm{N}$} & \multicolumn{2}{c|}{$\mathrm{P}$} & \multicolumn{2}{c|}{ K } \\
& $1982-84$ & 2000 & $1982-84$ & 2000 & $1982-84$ & 2000 \\
\hline Kenya & -41 & -47 & -6 & -7 & -29 & -36 \\
Tanzania & -27 & -32 & -4 & -5 & -18 & -21 \\
Rwanda & -54 & -60 & -9 & -11 & -47 & -61 \\
\hline
\end{tabular}

(Bekunda, et al., 2004)

\section{Land equivalent ratio (LER)}

Intercropping of cereals with legumes has been an ordinary cropping system in different arid and semi-arid areas of SSA. In an effort to assess the efficiency of intercropping over monocropping, scientists use different competition indices (Hiebesch and McCollum, 1987). However, Land Equivalent Ratio (LER) is the most used convention for intercrop versus sole crop comparisons (Agegnehu, 2006). LER provides an accurate assessment of the competitive relationship between the component plants in an intercropping, as well as the overall productivity of intercrop systems (Zada et al., 1988). LER measures how efficient are intercropping or mixture. The LER makes comparison of land areas required under single or sole cropping to give the yields obtained from the component crops of the mixture (Federer and Schwager, 1982). If the intercropped crops have the same agro-ecological characteristics, their total LER should be 1.0 and their partial LER should be 0.5 for each crop. Dariush $e t$ al. (2006) and Mohammed (2011) pointed out that if a total of LER is greater than 1.0 signifies that the positive inter-specific interference that exist in the monoculture is intensive than that in the mixture. The LER value of 1.0 indicates that the yield of intercrop are the same as those of the collections of monocultures and any value greater than 1.0 indicates the advantage for intercropping (Kutrata, 1986; Mazaheri and
Moveysi, 2004). The comparative advantages of intercropped crops over sole crops may be influenced by many factors such as crop density and soil nutritional status. Rhizobia inoculation and supplementation of phosphorus and potassium may influence yield performance of intercropped crops, and therefore, it is important to assess their effects on land equivalent ratio.

In conclusion, this review focused on the potential effects of rhizobial inoculation, phosphorus and potassium fertilization in legume-cereal intercropping systems on nitrogen fixation; mineral composition in the crop rhizosphere; nutrient uptake in plants; plant growth; photosynthesis and leaf chlorophyll content; yield performance of legumes and cereals and finally land equivalent ratio. The results from different literatures cited showed that Rhizobium inoculation and supplementation with phosphorus and potassium had positive significant effects on all parameters measured. Therefore, when these biofertilizers are used and supplemented with optimum levels of phosphorus and potassium they can significantly increase both legumes and cereals production. Based on these results, it is recommended to use rhizobia inoculants supplemented with optimum levels of phosphorus and potassium in the intercropping systems for production of high yield in highly depleted soils. However, more studies are required to 
explore whether the increased plant performances are mainly due to plantmicrobes interactions or due to other underlying factors.

\section{Acknowledgements}

Special thanks to the Government of Tanzania, through Nelson Mandela African Institution of Science and Technology (NMAIST) for supporting this study.

\section{References}

Ae, N., Arihara, J., Okada, K., Yoshihara, T., Johansen, C. 1990. Phosphorus uptake by pigeon pea and its role in cropping systems of the Indian subcontinent. Sci., 248(4954): 477-480.

Agegnehu, G., Ghizaw, A., Sinebo, W. 2006. Yield performance and land-use efficiency of barley and faba bean mixed cropping in Ethiopian highlands. Eur. J. Agron., 25(3): 202-207.

Agegnehu, G., Ghizaw, A., Sinebo, W. 2008. Yield potential and land-use efficiency of wheat and faba bean mixed intercropping. Agron. Sustainable Dev., 28(2): 257-263.

Akram, A., Fatima, M., Ali, S., Jilani, G., Asghar, R. 2007. Growth, yield and nutrients uptake of sorghum in response to integrated phosphorus and potassium management. Pakistan J. Bot., 39(4): 1083.

Amesz, J. 1987. Photosynthesis. Elsevier, Amsterdam.

Andersen, M.K., Hauggaard-Nielsen, H., HøghJensen, H., Jensen, E.S. 2007. Competition for and utilisation of sulfur in sole and intercrops of pea and barley. Nutr. Cycl. Agroecosys., 77(2): 143-153.

Andrews, R.W. 1979. Intercropping, Its importance and research need I.Competition and yield advantages. Field Crop. Abstr., 32: 1-10.

Arnon, D.I., Stout, P.R. 1939. The essentiality of certain elements in minute quantity for plants with special reference to copper. Plant physiol., 14(2): 371-375.
Arumugam, R., Rajasekaran, S., Nagarajan, S.M. 2010. Response of Arbuscular mycorrhizal fungi and Rhizobium inoculation on growth and chlorophyll content of Vigna unguiculata (L) Walp Var. Pusa 151.J. Appl. Sci. Environ. Manag., 14(4): 113 - 115.

Bambara, S., Ndakidemi, P.A. 2009. Effects of Rhizobium inoculation, lime and molybdenum on photosynthesis and chlorophyll content of Phaseolus vulgaris L. Afr. J. Microbiol. Res., 3(11): 791-798.

Bambara, S., Ndakidemi, P.A. 2010. Phaseolus vulgaris response to Rhizobium inoculation, lime and molybdenum in selected low $\mathrm{pH}$ soil in Western Cape, South Africa. Afr. J. Agric. Res., 5(14): 1804-1811.

Bambara, S., Ndakidemi. P.A. 2010. Changes in selected soil chemical properties in the rhizosphere of Phaseolus vulgaris L. supplied with Rhizobium inoculants, molybdenum and lime. Sci. Res. Essays, 5(7): 679-684.

Banik, P., Bagchi, D.K. 1993. Effect of legumes as sole and intercrop on residual soil fertility and succeeding crop in upland situation. Indian Agric., 26: 58-64.

Bationo, A., Ntare, B., Tarawali, S., Tabo, R. 2002. Soil Fertility Management and Cowpea Production in the Semiarid Tropics, In: Fatokun, C.A., Tarawali, S.A., Singh, B.B., Kormawa, P.M., Tamo, M. (ed.) Challenges and Opportunities for Enhancing Sustainable Cowpea Production, IITA, Ibadan, 301-318.

Bekunda, M.A., Nkonya, E., Mugendi, D., Msaky, J.J. 2004. Soil fertility status, management, and research in East Africa. East Afr. J. Rural Dev., 20(1): 94-112.

Blagodatskaya, E., Kuzyakov, Y. 2008. Mechanisms of real and apparent priming effects and their dependence on soil microbial biomass and community structure: critical review. Biol. Fert. Soils, 45(2): 115-131.

Brady, N.C. 2002. Phosphorus and potassium. In: The nature and properties of soils. Prentice-Hall of India, Delhi, pp352.

Britto, D.T., Kronzucker, H.J. 2008. Cellular mechanisms of potassium transport in 
plants. Physiol. Plantarum, 133(4): 637650.

Buerkert, A., Bationo, A., Piepho, H.P. 2001. Efficient phosphorus application strategies for increased crop production in subSaharan West Africa, Field Crop. Res., 72(1): $\quad 1-15$. doi:10.1016/S03784290(01)00166-6.

Carr, P.M., Horsley, R.D., Poland, W.W. 2004. Barley, oat, and cereal-pea mixtures as dryland forages in the northern Great Plains. Agron. J., 96(3): 677-684.

Cechin, I., de Fátima Fumis, T. 2004. Effect of nitrogen supply on growth and photosynthesis of sunflower plants grown in the greenhouse. Plant Sci., 166(5): $1379-1385$.

Chianu, J.N., Nkonya, E.M., Mairura, F.S., Akinnifesi, F.K. 2011. Biological nitrogen fixation and socioeconomic factors for legume production in sub-Saharan Africa: a review. Agron. Sustain. Dev., 31: 139154

Cu, S.T., Hutson, J., Schuller, K.A. 2005. Mixed culture of wheat (Triticum aestivum L.) with white lupin (Lupin usalbus L.) improves the growth and phosphorus nutrition of the wheat. Plant Soil, 272(12): 143-151.

Dahmardeh, M., Ghanbari, A., Syahsar, B.A., Ramrodi, M., 2010. The role of intercropping maize (Zea mays L.) and cowpea (Vigna unguiculata L.) on yield and soil chemical properties. Afr. J. Agric. Res., 5(8): 631-636.

Dariush, M., M. Ahad and O. Meysam. 2006. Assessing the land equivalent ratio (LER). Of two corn (Zea mays L.) varieties intercropping at various Nitrogen Levels in Karaj, Iran. J. Cent. Eur. Agric., 7(2) 359- $364 . \quad$ doi: 10.5829/idosi.ijmr..3.1.61103.

Dusa, E.M., Stan, V., 2013. The effect of intercropping on crop productivity and yield quality of oat (Avena sativa L.)/grain leguminous species (Pea-Pissum sativum L., Lentil-Lens culinaris L.) cultivated in pure stand and mixtures, in the organic agriculture system. European Scientific J., 9(21): 69-78.

Fageria, N.K., Zimmermann, F.J.P., Baligar,
V.C. 1995. Lime and phosphorus interactions ongrowth and nutrient uptake by upland rice, wheat, common bean, and corn in an Oxisol. J. Plant Nutr., 18(11): 2519-2532.

Fan, F., Zhang, F., Song, Y., Sun, J., Bao, X., Guo, T., Li, L. 2006. Nitrogen fixation of faba bean (Vicia faba L.) interacting with a non-legume in two contrasting intercropping systems. Plant Soil, 283(12): 275-286.

Fatima, Z., Zia, M., Chaudhary, M.F. 2007. Interactive effect of Rhizobium strains and $\mathrm{P}$ on soybean yield, nitrogen fixation and soil fertility. Pak. J. Biotechnol., 39(1): 255-264.

Federer, W.T., Schwager, S.J. 1982. On the distribution of land equivalent ratios. Unpublished Technical Report BU-777-M in the Technical Report Series of the Biometrics Unit, Cornell University, Ithaca, NY.

Flynn, R., Idowu, J., (undated). Nitrogen Fixation by Legumes. Guide A-129, New Mexico State University. http://aces.nmsu.edu/pubs/_a/A129/ [Accessed 31.07.2016]

Francis, C.A. 1986. Distribution and importance of multiple cropping. Multiple cropping. New York: McMillan, 15-19.

Frankow-Lindberg, B.E., Dahlin, A.S. 2013. N2 fixation, $\mathrm{N}$ transfer, and yield in grassland communities including a deep-rooted legume or non-legume species. Plant Soil, 370: 567-581. DOI 10.1007/s11104-0131650-z.

Gaidos, E.J., Nealson, K.H., Kirschvink, J.L., 1999. Life in ice-covered oceans. Sci., 284(5,420), 1631-1633.

Gardner, W.K., Boundy, K.A., 1983. The acquisition of phosphorus by Lupin usalbus L., 4: The effect of inter planting wheat and white lupin on the growth and mineral composition of the two species. Plant and Soil (Netherlands).

Ghanbari, A., Dahmardeh, M., Siahsar, B.A., Ramroudi, M., 2010. Effect of maize (Zea mays L.)-cowpea (Vigna unguiculata L.) intercropping on light distribution, soil temperature and soil moisture in arid environment. J. Food Agric. Environ., 
8(1), 102-108.

Ghosh, P.K., 2004. Growth, yield, competition and economics of groundnut/cereal fodder intercropping systems in the semi-arid tropics of India. Field Crop. Res., 88(2), 227-237.

Giller, K.E., Wilson, K.J., 1991. Nitrogen Fixation in Tropical Cropping Systems. CAB International, Wallingford, UK.

Hauggaard-Nielsen, H., Gooding, M., Ambus, P., Corre-Hellou, G., Crozat, Y., Dahlmann, C., Dibet, A., von Fragstein, P., Pristeri, A., Monti, M., Jensen, E.S., 2009. Pea-barley intercropping for efficient symbiotic $\mathrm{N}_{2}$-fixation, soil $\mathrm{N}$ acquisition and use of other nutrients in European organic cropping systems. Field crop. res. 113(1), 64-71.

Hayat, R., Ali, S., Amara, U., Khalid, R., Ahmed, I., 2010. Soil beneficial bacteria and their role in plant growth promotion: a review. Ann. Microbiol. 60(4), 579-598.

Hedin, L.O., Vitousek, P.M., Matson, P.A., 2003. Nutrient losses over four million years of tropical forest development. Ecol., 84: 2231-2255.

Hernández, M., Cuevas, F., 2003. The effect of inoculating with arbuscular mycorrhiza and Bradyrhizobium strains on soybean (Glycine $\max$ (L.) Merrill) crop development. Cultivos Tropicales, 24(2), 19-21.

Hiebesch, C.K., McCollum, R.E., 1987. Areaxtime equivalency ratio: a method for evaluating the productivity of intercrops. Agron. J., 79: 15-22.

Hirpa, T. 2013. Maize productivity as affected by intercropping date of companion legume crops. Peak J. Agric. Sci., 1(5): 70-82.

Hirpa, T. 2014. Response of maize crop to spatial arrangement and staggered inter seeding of haricot bean. Int. J. Environ., 3(3): 126-138.

Hossain, M.D., Musa, M.H., Talib, J., Jol, H., 2010. Effects of nitrogen, phosphorus and potassium levels on kenaf (Hibiscus cannabinus L.) growth and photosynthesis under nutrient solution. J. Agr. Sci., 2(2), 49-57.

Islam, M.A., Islam, M.R., Sarker, A.B.S., 2008.
Effect of phosphorus on nutrient uptake of Japonica and Indica rice. $J$. Agric. Rural Dev., 6(1), 7-12.

Islam, M.T., Kubota, F., Mollah, F.H., Agata, W., 1993. Effect of shading on the growth and yield of mung bean (Vigna radiata [L.] Wilczek). J. Agron. Crop Sci., 171(4), 274-278.

Israel, D.W., 1987. Investigation of the role of phosphorus in symbiotic dinitrogen fixation. Plant Physiol., 84(3), 835-840.

James, E.K., 2000. Nitrogen fixation in endophytic and associative symbiosis. Field Crop. Res., 65(2): 197209.

Jensen, E.S., 1996. Grain yield, symbiotic N2 fixation and interspecific competition for inorganic $\mathrm{N}$ in pea-barley intercrops. Plant Soil, 182, 25-38.

Kaschuk, G., Kuyper, T.W., Leffelaar, P.A., Hungria, M., Giller, K.E., 2009. Are the rates of photosynthesis stimulated by the carbon sink strength of rhizobial and arbuscular mycorrhizal symbioses. Soil Biol. Biochem., 41(6), 1233-1244.

Khogali, M.E., Ahmed E.E.A., El Huweri, S.O., 2011. Effect of Nitrogen, Intercropping With Lablab Bean (Lablab purpureus) and Water Stress on Yield and Quality of Fodder Maize. J. Sc. Tech., 12 (03), 55-66.

Kloepper, J.W., Ryu, C.M., Zhang, S., 2004. Induced systemic resistance and promotion of plant growth by Bacillus spp. Phytopathol., 94(11), 1259-1266.

Kutrata, T., 1986. A study on farming system in USSA. Quarterly. J. Agro. Eco., 26: 179205.

Lamrani, Z., Belakbir, A., Ruiz, J.M., Ragala, L., López- Cantarero, I., Romero, L., 1996. Influence of nitrogen, phosphorus, and potassium on pigment concentration in cucumber leaves. Commun. Soil Sci. Plan., 27(5-8), 1001-1012.

Ledgard, S.F., Steele, K.W., 1992. Biological nitrogen fixation in mixed legume/grass pastures. Plant Soil, 141(1-2), 137-153.

Lemlem, A., 2013. The effect of intercropping maize with cowpea and lablab on crop yield. Herald J. Agric. Food Sci. Res., 2(5), $156-170$

Li, L., Sun, J., Zhang, F., Li, X., Yang S., 
Rengel, Z., 2001. Wheat/maize or wheat/soybean strip intercropping: I. Yield advantage and interspecific interactions on nutrients. Field Crop. Res. 71(2), 123-137.

Li, L., Yang, S., Li, X., Zhang, F., Christie, P., 1999. Interspecific complementary and competitive interactions between intercropped maize and faba bean. Plant and Soil, 212(2), 105-114.

Li, L., Zhang, F., Li, X., Christie, P., Sun, J., Yang, S., Tang, C., 2003. Interspecific facilitation of nutrient uptake by intercropped maize and faba bean. Nutr. Cycl. Agroecosys. 65(1), 61-71.

Lissbrant, S., Berg, W.K., Volenec, J., Brouder, S., Joern, B., Cunningham, S., Johnson, K., 2009. Phosphorus and Potassium Fertilization of Alfalfa. Purdue Cooperative Extension Service Publication AY-331-W.

Longstreth, D.J., Nobel, P.S., 1980. Nutrient influences on leaf photosynthesis effects of nitrogen, phosphorus, and potassium for Gossypium hirsutum L. Plant Physiol., 65(3), 541-543.

Maass, B.L., Knox, M.R., Venkatesha, S.C., Angessa, T.T., Ramme S., Pengelly, B.C., 2010. Lablab purpureus - a crop lost for Africa? Tropical Plant Biol., 3(3): 123135. doi:10.1007/s12042-010-9046-1

Mäder, P., Fliessbach, A., Dubois, D., Gunst, L., Fried, P., Niggli, U., 2002. Soil fertility and biodiversity in organic farming. Sci., 296(5573), 1694-1697.

Makoi, J.H.J.R., Bambara, S., Ndakidemi, P.A., 2013. Rhizobium inoculation and supply of Molybdenum and lime affect the uptake of microelements in common bean ( $P$. vulgaris L.) Plants. Aust. J. Crop Sci., 7(6),784-793.

Masarirambi, M.T., Hlawe, M.M., Oseni O.T., Sibiya, T.E., 2010. Effects of organic fertilizers on growth, yield, quality and sensory evaluation of red lettuce (Lactuca sativa L.) 'Veneza Roxa'. Agric. Biol. J. N. Am. 1(6), 1319-1324

Matiru, V.N., Dakora. F.D., 2004. Potential use of rhizobial bacteria as promoters of plant growthfor increased yield in landraces of African cereal crops. Afr. J. Biotechnol.
$3(1): 1-7$

Matusso, J.M.M., Mugwe, J.N., Mucheru-Muna, M., 2012. Potential role of cereal-legume intercropping systems in integrated soil fertility management in smallholder farming systems of sub-Saharan Africa. Third RUFORUM Biennial Meeting 24 28 September 2012, Entebbe, Uganda. 1815- 1843

Matusso, J.M.M., Mugwe, J.N., Mucheru-Muna, M., 2014. Potential role of cereal-legume intercropping systems in integrated soil fertility management in smallholder farming systems of sub-Saharan Africa. Res. J. Agric. Environ. Manage. 3(3), 162-174.

Mazaheri, D., Oveysi M., 2004. Effects of intercropping of two corn varieties at various nitrogen levels. Iran. J. Agron., 1: 71-76.

Menaria, B.L., Pushpendra, S., Nagar, R.K., Singh, P., 2003. Effect of Nutrients and Microbial Inoculants on Growth and Yield of Soybean [Glycine max (L.) Merril]. J. Soils and Crops, 13(1), 14-17.

Mengel, K., Haghparast, M.R., Koch, K., 1974. The effect of potassium on the fixation of molecular nitrogen by root nodules of Vicia faba. Plant Physiol. 54(4), 535-538.

Mia, M.B., Shamsuddin, Z.H., 2010. Rhizobium as a crop enhancer and biofertilizer for increased cereal production. Afr. J. Biotechnol. 9(37), 6001-6009.

Mobasser, H.R., Vazirimehr, M.R., Rigi, K., 2014. Effect of intercropping on resources use, weed management and forage quality. Int. J. Pl. An. and Env. Sci. 4(2), 706-713.

Mohammed, S.A.A., 2011. Assessing the Land Equivalent Ratio (LER) of Two Leguminous Pastures (CLITORIA and SIRATRO) Intercropping at Various Cultural Practices and Fencing at ZALINGEI-Western Darfur State-Sudan.

Morris, R.A., Garrity, D.P., 1993. Resource capture and utilization in intercropping; non-nitrogen nutrients. Field Crop. Res. 34(3), 319-334.

Mwangi, W.M., 1996. Low use of fertilizers and low productivity in sub-Saharan Africa. Nutr. Cycl. Agroecosys. 47(2), 135-147. 
Ndakidemi P.A., 2006. Manipulating legume/cereal mixtures to optimize the above and below ground interactions in the traditional African cropping systems. Afr. J. Biotechnol. Vol. 5 (25), pp. 25262533.

Ndakidemi, P.A., Bambara, S., Makoi, J.H.J.R., 2011. Micronutrient uptake in common bean('Phaseolus vulgaris' L.) as affected by Rhizobium inoculation, and the supply of molybdenum and lime. Plant Omics. 4:40-52.

Ndakidemi, P.A., Dakora, F.D., Nkonya, E.M., Ringo D., Mansoor. H., 2006. Yield and economic benefits of common bean (Phaseolus vulgaris) and soybean (Glycine max) inoculation in northern Tanzania. Aust. J. Exp. Agr. 46, 571-577

Nyoki, D., Ndakidemi, P.A., 2014a. Influence of Bradyrhizobium japonicum and phosphorus on micronutrient uptake in cowpea. A case study of zinc ( $\mathrm{Zn}$ ), iron $(\mathrm{Fe})$, copper $(\mathrm{Cu})$ and manganese $(\mathrm{Mn})$. Am. J. Plant Sci. 5(4), 427-435.

Nyoki, D., Ndakidemi. P.A., 2014b. Effects of Bradyrhizobium japonicum inoculation and supplementation with phosphorus on macronutrients uptake in cowpea (Vigna unguiculata (L.) Walp). Am. J. Plant Sci. 5(4), 442-451

Onanuga, A.O., Jiang, P.A., Adl, S.M., 2011. Phosphorus, potassium and phytohormones promote chlorophyll production differently in two cotton (Gossypium hirsutum) varieties grown in hydroponic nutrient solution. J. Agr. Sci. 4(2), p157.

Parmar, P., Sindhu, S.S., 2013. Potassium solubilization by rhizosphere bacteria: influence of nutritional and environmental conditions. J. Microbiol. Res., 3(1), 25-31.

Peoples, M.B., Craswell, E.T., 1992. Biological nitrogen fixation: investments, expectations and actual contributions to agriculture. Plant soil, 141(1-2), 13-39.

Peoples, M.B., Giller, K.E., Herridge, D.F., Vessey, J.K., 2002. Limitations to biological nitrogen fixation as a renewable source for nitrogen for agriculture. In: Finan, T., O'Brian, M., Layzell, D., Vessey, K., Newton, W. (Eds.), Nitrogen
Fixation: Global Perspective. CAB International, UK pp356-360.

Peoples, M.B., Herridge, D.F., Ladha, J.K., 1995. Biological nitrogen fixation: an efficient source of nitrogen for sustainable agricultural production. Plant and soil, 174(1-2), 3-28.

Popescu, A., 1998. Contributions and limitations to symbiotic nitrogen fixation in common bean (Phaseolus vulgaris L.) in Romania. Plant Soil, 204(1), 117-125.

Pretty, J.N., Morison, J.I., Hine, R.E., 2003. Reducing food poverty by increasing agricultural sustainability in developing countries. Agriculture, ecosystems and environment, 95(1), 217-234.

Rabinowitch, E., Govindjee, (1969). Photosynthesis, John Wiley and Son, Inc. New Yock. USA. 284 pp.

Raji, J.A., 2007. Intercropping soybean and maize in a derived savanna ecology. Afr. J. Biotechnol., 6(16).1885-1887.

Raynaud, X., Jaillard, B., Leadley, P.W., 2008. Plants may alter competition by modifying nutrient bioavailability in rhizosphere: a modeling approach. The American Naturalist, 171(1), 44-58.

Roy, R., Finck, A., Blair, G., Tandon, H., 2006. Plant nutrition for food security. FAO fertilizer and plant nutrition bulletin 16 . Food and Agriculture Organization, Rome. 348 pp.

Saharan, B., Nehra, V., 2011. Plant growth promoting rhizobacteria: A critical review. Life Sci. Med. Res., 21: 1-30.

Saini, V.K., Bhandari, S.C., Tarafdar, J.C., 2004. Comparison of crop yield, soil microbial $\mathrm{C}, \mathrm{N}$ and $\mathrm{P}, \mathrm{N}$-fixation, nodulation and mycorrhizal infection in inoculated and non-inoculated sorghum and chickpea crops. Field Crop Res., 89: 39-47.

Salvagiotti, F., Cassman, K.G., Specht, J.E., Walters, D.T., Weiss, A., Dobermann, A., 2008. Nitrogen uptake, fixation and response to fertilizer $\mathrm{N}$ in soybeans: $\mathrm{A}$ review. Field Crop Res., 108(1), 1-13.

Sanchez, P.A., 1976. Properties and management of soils in the tropics. Wiley, New York. pp. 478-532.

Santi, C., Bogusz, D., Franche, C., 2013. Biological nitrogen fixation in non-legume 
plants. Ann. Bot. London. 111(5), 743767.

Shahid, M.Q., Saleem, M.F., Khan, H.Z., Anjum, S.A., 2009. Performance of soybean (Glycine max L.) under different phosphorus levels and inoculation. Pak. J. Agri. Sci. 46(4), 237-241.

Sharma, P.S., Ramna, S., 1993. Response of sorghum to nitrogen and potassium in an Alfisol. J. Potash. Res. 9(27), 171-175.

Sheahan, C.M., 2012. Plant guide for lablab (Lablab purpureus).USDA-Natural Resources Conservation Service, Cape May Plant Materials Center. Cape May, NJ. 08210.

Shen, Q.R., Chu, G.X., 2004. Bi-directional nitrogen transfer in an intercropping system of peanut with rice cultivated in aerobic soil. Biol. Fertil. Soils, 40, 81-87.

Shridhar, B.S., 2012. Review: Nitrogen Fixing Microorganisms, Int. J. Microbiol. Res. 3(1): 46-52.

Singh, A., Baoule, A., Ahmed, H., Dikko, A., Aliyu, U., Sokoto, M., Alhassan, J., Musa, M., Haliru, B., 2011. Influence of phosphorus on the performance of cowpea (Vigna unguiculata (L) Walp.) varieties in the Sudan savanna of Nigeria, Agri. Sci., 2(3), 313-317.

Singh, B., Usha, K., (2003). Nodulation and symbiotic nitrogen fixation of cowpea genotypes as affected by fertilizer nitrogen. J. Plant Nutr. 26(2), 463-473.

Song, Y.N., Zhang, F.S., Marschner, P., Fan, F.L., Gao, H.M., Bao, X.G., Sun J.H., Li, L., 2007. Effect of intercropping on crop yield and chemical and microbiological properties in rhizosphere of wheat (Triticum aestivum L.), maize (Zea mays L.), and faba bean (Vicia faba L.). Biol. Fert. Soils, 43(5), 565-574.

Stern W.R., 1993. Nitrogen fixation and transfer in intercrop systems. Field Crop. Res., 34, 335-356.

Syers, J.K., Johnston, A.E., Curtin, D., 2008. Efficiency of soil and fertilizer phosphorus use. FAO Fertilizer and Plant Nutrition Bull., 18.

Tairo, E.V., Ndakidemi, P.A., 2014. Macronutrients Uptake in Soybean as Affected by Bradyrhizobium japonicum
Inoculation and Phosphorus (P) Supplements" Am. J. Plant Sci. 5(4): 488496

Tang, C., Hinsinger, P., Drevon, J.J., Jaillard, B., 2001. Phosphorus deficiency impairs early nodule functioning and enhances proton release in roots of Medicago truncatula $\mathrm{L}$. Ann. Bot-London, 88(1), 131-138.

Uchida, R.S., 2000. Essential nutrients for plant growth: nutrient functions and deficiency symptoms. In: Silva, J.A., Uchida, R.S. (Eds.), Plant nutrient management in Hawaii soils. Manoa College of Tropical Agriculture and Human Resources, University of Hawaii at Manoa.31-55.

Valenzuela, H., Smith, J., 2002. Sustainable agriculture green manure crops. SA-GM7. Cooperative Extension Service, College of Tropical Agric. and Human Resources, Univ. of Hawaii at Manoa.

Vargas, M.A., Mendes, I.C., Hungria, M. 2000. Response of field-grown bean (Phaseolus vulgaris $\mathrm{L}$.) to Rhizobium inoculation and nitrogen fertilization in two Cerrados soils. Biol. Fert. Soils. 32(3), 228-233.

Vincent, J.M., Nutman, P.S., Skinner, F.A., 1979. The identification and classification of Rhizobium. In: Shinner, F.A., Lovelock, D.W. (Eds.), Methods for microbiologists. (Society for applied bacteriology, technical series no 14) Academic Press, London.

Walley, F.L., Tomm, G.O., Matus, A., Slinkard, A.E., van Kessel, C., 1996. Allocation and cycling of nitrogen in an alfalfabromegrass sward. Agron. J. 88: 834-843.

Westhoff, P., 2009. The economics of biological nitrogen fixation in the global economy. Nitrogen fixation in crop production. Agron. Monogr, 52, 309-328.

Whitbread, A.M., Ayisi, K.K., 2004. Description of the biophysical environment of three maize-producing areas in the Limpopo Province of the Republic of South Africa and the validation of APSIM to simulate maize production. Tropical Legumes for Sustainable Farming Systems in Southern Africa and Australia, ACIAR Proceedings, No. 115,180p.

White, P. J., Broadley, M.R., Gregory, P.J., 2012. Managing the Nutrition of Plants 
and People. Appl. Environ Soil Sci. Vol. 2012, 1-14.

Wu, C., Wang, Z., Sun, H., Guo, S., 2006. Effects of different concentrations of nitrogen and phosphorus on chlorophyll biosynthesis, chlorophyll a fluorescence, and photosynthesis in Larix olgensis seedlings. Front. for China, 1(2), 170-175.

Xu, B.C., Li, F.M., Shan, L., 2008. Switchgrass and milkvetch intercropping under 2: 1 row-replacement in semiarid region, northwest China: Aboveground biomass and water use efficiency. Eur. J. Agron. 28(3), 485-492.

Yamanaka, T., Akama, A., Li, C.Y., Okabe, H., 2005. Growth, nitrogen fixation and mineral acquisition of Alnus sieboldiana after inoculation of Frankia together with Gigaspora margarita and Pseudomonas putida. J. For. Res. 10(1), 21-26.

Yang, J., Kloepper, J.W., Ryu, C.M., 2009. Rhizosphere bacteria help plants tolerate abiotic stress. Trends in plant sci., 14(1), 1-4.

Yoshida, S., Hara, T., 1977. Effects of air temperature and light on grain filling of an indica and a japonica rice (Oryza sativa L.) under controlled environmental conditions. Soil Sci. Plant Nutri., 23(1): 93-107.

Zada, K., Ahmad, S., Nazar, M.S., 1988. Land Equivalent Ratio, Relative Yield and relative yield total of intercropped maize and soybean. Pakistan J. Agric. Res., 9(4),
453-457

Zafar, M., Abbasi, M., Rahim, N., Khaliq, A., Shaheen, A., Jamil, M., Shahid, M., 2011. Influence of integrated phosphorus supply and plant growth promoting rhizobacteria on growth, nodulation, yield and nutrient uptake in Phaseolus vulgaris. Afr. J. Biotechnol., 10(74), 16793-16807.

Zahran, H.H., 1999. Rhizobium-legume symbiosis and nitrogen fixation under severe conditions and in an arid climate. Microbiol. Mol. Biol. Rev., 63(4), 968-989.

Zhang, F., Li. L., 2003. Using competitive and facilitative interactions in intercropping systems enhances crop productivity and nutrient-use efficiency. Plant and soil, 248(1-2): 305-312.

Zhang, F., Shen, J., Li, L., Liu, X. 2004. An overview of rhizosphere processes related with plant nutrition in major cropping systems in China. Plant and Soil, 260(12): 89-99.

Zhao, D., Oosterhuis, D.M., Bednarz, C.W. 2001. Influence of potassium deficiency on photosynthesis, chlorophyll content, and chloroplast ultra structure of cotton plants. Photosynthetica, 39(1): 103-109.

Zhou X.M., Chandra, A.M., Angus, F.M., Kaluli, J.W., Smith, D.L. 2000. Corn yield and fertilizer $\mathrm{N}$ recovery in water-table controlled corn-rye-grass. Eur. J. Agron., 12: 83-92.

\section{How to cite this article:}

Daniel Nyoki and Patrick A. Ndakidemi. 2016. Intercropping System, Rhizobia Inoculation, Phosphorus and Potassium Fertilization: A Strategy of Soil Replenishment for Improved Crop Yield. Int.J.Curr.Microbiol.App.Sci. 5(10): 504-522.

doi: http://dx.doi.org/10.20546/ijcmas.2016.510.056 